\title{
Refusing Consumption and Querying Genre: a partial reading of Marie NDiaye
}

Judith Still

\begin{abstract}
Even thinking (at) the border of thought, images and dreams (perhaps semi-fictions), inevitably raises questions of genre and how we read: what is the effect of the words (syllables, letters, sounds), and what is their affect? Does the phrase 'unidentifiable literary object' help us imagine both the impossibility of identifying or deciding, and the inevitability, need or desire to figure something out? The dialogue between Jacques Derrida and Hélène Cixous is sometimes framed as an encounter between a man and a woman, friends for life or 'till death do us part'. What's the difference? Cixous, Derrida says, does not believe in death - while he keeps reminding her of the inevitable parting too soon - which of course she knows, and writes about, very well. I shall track these questions in a novel identified as contemporary 'Francophone women's writing'. There is plenty of food for thought (of life, of death) in NDiaye's La Cheffe, roman d'une cuisinière (2016), a novel which perversely stages (perhaps literary inter alia) creation by first the cooking of a dead chicken, and then eventually the serving up of the imaginary of a chicken by gazing on living chickens. Consuming flesh and consuming words or stories, the gift of creativity, intersects with genre in both its meanings - I try to do justice to the complexity of the textual e/affects.
\end{abstract}

\section{Keywords}

Marie Ndiaye, La Cheffe, cooking, disorderly eating, chickens, Derrida, Cixous

\section{Introductory thoughts}

Even thinking (at) the border of thought (what we might call semi-theory), or writing or speaking words, images, or dreams (perhaps semi-fictions ${ }^{1}$ ), inevitably raises questions of genre, in both senses, and how we read: what is the effect of the words (syllables, letters, sounds), and what is their affect, the passions evoked and aroused? Does the phrase 'unidentifiable literary object [objet littéraire non identifiable]' ${ }^{2}$ (ULO) help us imagine both the delirious impossibility of identifying or deciding (la folie), and also the inevitability, need or desire to play the rational detective, to figure something out?

The dialogue between Jacques Derrida and Hélène Cixous is sometimes framed as an encounter between a man and a woman, or a philosopher and a poet, friends for life or 'till death do us part'. What's the difference? Is it positively feminine to say yes, to give life rather than death (it works better in French)? Cixous, Derrida says, does not believe in death - while he keeps reminding her of the inevitable parting too soon - which of course she knows, and writes about, very well. ${ }^{3}$ In his H.C. for Life, That is to Say... [H.C. pour la vie, c'est à dire...] 'C. pour la vie'suggests that 'Cixous' is 'pour la vie'; she's for life, on the side of life; the homophone 'c'est pour la vie' suggests it's for life, in more senses than one including a friend for life. Derrida's typically patient unpicking of his title, and of her titles, is an emblem of slow reading, the banner then unfurled as he lovingly cites (sides, at her side, on her side $)^{4}$ from within. The attention at the level of the letter, or the syllable, intertwines with the spirit ('et pour l'esprit et pour la lettre de la lettre [both for the spirit and for the letter of the letter]'), heightening the poetry embedded in the prose. ${ }^{5}$ 
I shall track these questions in a novel by Marie Ndiaye, whose work is usually quickly identified as contemporary 'Francophone women's writing' - helpfully, or perhaps unhelpfully from the point of view of slow reading. Cixous too is a Francophone woman writer though not so often identified as such - certainly not when she first started publishing. ${ }^{6}$ In tracking words, I am almost following - je suis - the master (maître à penser, so difficult to translate, not quite the same as a chef), but I am not - je ne suis pas - the master, heaven forfend a mistress. There is plenty of food for thought (of life, of death) in NDiaye's La Cheffe, roman d'une cuisinière, a novel which perversely stages creation not by a simple mise en abyme but by a central focus on the practice of cooking, and the one who excels at this semi-art. ${ }^{7}$ La Cheffe's cooking of a dead chicken eventually becomes the serving up of the imaginary of a chicken by gazing on living chickens. Both scenes hover crazily between life and death although the first, the primal scene of creativity, can only be interpreted as lethal in retrospect. The text takes shape as a game of hide and seek between a man and a woman, friends or lovers, one dead before the start of writing, the survivor a detective-cannibal. Consuming or producing flesh and consuming or producing words or stories - the gift of creativity - intersects with genre in both its meanings. The possibility of an unidentifiable literary object is phrased here as an impossible meal, a meal which literally does not exist; the spirit of the meal might be imagined (telepathically) in communion between those who are then both producer-consumers even if one of them (la Cheffe) has orchestrated it. The spectacle of life is more successful than a material assemblage of dead things to feed the body, if the woman is right - although the man, hungering, more focused on mourning the fact of parting too soon, provides a more sceptical philosophical voice in spite of his delight in her joyous creations.

\section{What's in a Name? The Title is: La Cheffe, roman d'une cuisinière}

Let's begin at the beginning, or even before the beginning, while La Cheffe is still an unidentified, if not yet determined as an unidentifiable, literary object. It is a weighty book published by Gallimard, a prestige editor, with the name of a prize-winning author on the cover so, yes, probably a literary object in the material sense, although ULO is split in contradiction - it identifies something as a literary object even as it names it unidentifiable. And so, what kind of appeal does NDiaye's book have for, or make to, the reader? It has the title or heading La Cheffe, roman d'une cuisinière. What is La Cheffe? A strange wordobject, an oddity for NDiaye who (unlike, say, Monique Wittig or Cixous) is not known for coining neologisms. It is bizarre because of genre in the sense of gender. Le chef, from the Latin caput or head, is of course a common masculine noun referring to a special kind of man, a headman, a chief or chieftain, a leader in his field - giving him the title he has 'earned'. It implies a structure of power. The French and Francophones (notably in Quebec) have tentatively and controversially explored the feminization of many professional terms and the boss le chef can potentially become Madame le chef (the least subversive), la chef, la cheffesse (with sexual undertones in fesses or buttocks), even la cheftaine (in a Boy Scout or Girl Guide context); however, la cheffe is hard to find. It is a quasi-parricidal, untranslatable nugget for Anglophones since the homonym chef, never mind its impossible homophone cheffe, is not quite the same in the two languages. ${ }^{8}$ The primary meaning of le chef in French is relational in the world of work (meaning boss, superior in the chain of command) and not specifically chef de cuisine, as it is for the English chef (we Anglophones especially like to borrow from the French in the field of cookery). The gender question le/la is of course interminably untranslatable between English and French, if not between French and French where the debate over the sexual politics of grammatical genre is far from over. Derrida's 
attention to ' $l a$ ', the feminine definite article and inter alia the feminine preceding direct object (and also its homophone 'là', there, a shifting place), is a feature of much of his writing - including of course H.C. For Life. His The Beast and the Sovereign [La bête et le souverain] seminar series sets up the feminine-gendered beast rather than the animal (l'animal, a masculine noun) in part no doubt on account of that very difference.

In any case, in the title La Cheffe, roman d'une cuisinière, the invented word is almost explained; there is a quasi-identification, after a comma - but not a colon which would be, in English, a most appropriate figure of punctuation with its hidden connotation of digestion. A colon in fact (deux-points in French, the doubled full stop ${ }^{9}$ ) would work as i.e. 'that is to say', as a definition or identification, a spelling out. A comma, however, almost a comma splice, leaves a more uneasy if not queasy relationship between the two elements La Cheffe and roman d'une cuisinière. We move from specifying or perhaps querying gender in a striking fashion ( $L a$ Cheffe), to naming genre (roman), and then lapsing into bathos with the third noun (une cuisinière). La Cheffe is a novel or romance (and I shall turn to that when I have moved further into the beginning) - its genre is roman. It is the story d'une cuisinière - so how does the feminine noun la cuisinière relate to the masculine noun le chef? Well, la cuisinière is both a cook and a cooker or stove - it is the plainte (complaint or lament) of many a feminist that feminine forms often refer to objects as much as people, and, in their reference to human beings, to degraded forms. ${ }^{10}$ La cuisinière is often a servant - and thus not a leader in the structure of power though she might have some underlings. So perhaps this is not a high-flown, classy literary object then, perhaps it does not deal with top-flight passions, sensual bedchambers, stately salons or even dining rooms. What happens in la cuisine, where we might find une cuisinière, not even the cook but a cook or cooker, is generally domestic and everyday (producing something fairly mundane if pleasurable like 'aga sagas' consumed and forgotten). Domestic cooking is not of course the lowest, the most degraded, of activities (maybe that would be cleaning lavatories). Indeed, the superlative, 'the most' of anything, has value, a heroic quality if by antithesis - scenes located in a lavatory (with or without heroin or anal suppositories) have the power of provocation, épater le bourgeois - we are still in the world of machismo with one finger, or even, two fingers (another double) to the other side. No, the kitchen - sink or cooker - just brings the chef down to the banal and domestic, not haute cuisine but merely une cuisinière. ${ }^{11}$ A double feminine gender lurks in what might or might not be (the comma splice can split-link a list of non-identical objects) a subtitle: ' $u n e$ ' and the suffix 'ère'. Of course the feminine realm can be conquered by virile chefs, and the cuisine can rise from the back of the house to take a more starring role in today's consumer and consuming society - and in fact celebrity chefs have a long pedigree. (In the $19^{\text {th }}$ century the Vanderbilts imported their chef from France to the US.) But not here, where there are too many feminine elements - and even the universal and unique definite article of la Cheffe (she is always named 'la Cheffe', never 'une cheffe') slides in status, becomes the indefinite particular instance une cuisinière - as if she were one cook amongst many. This is despite the fact that la Cheffe will receive the poisoned gift of a Michelin star, the prix Goncourt in a novel that plays complex games with autofictional details.

Is cooking then, since you can be amongst the stars, a high art like poetry or a low craft like versification? Or is it in fact a hard science, challenging to learn with precision (molecular gastronomy with a touch of the Parnassian)? Or an intuitive process - intuition which can be feminine or the mark of genius? Do chefs measure the amount of salt or sugar with careful quantification or judge the quality by taste? Are chefs intelligent or creatures of appetite? Are they like military leaders running kitchens like clockwork, and/or abusing their underlings whether precisely, or brutishly and chaotically? I give you a series of questions. Just as the 
apprentice chef who authors the work La Cheffe seeks to track his beloved master chef (not a mistress), cooking and analysing, perhaps I am following in the steps (pas à pas), stealthily like a wolf please, rather than a birdbrained-chicken, of the mastermind (what a misnomer), with the ruse of the question, the lure of the negative, the feint and the delay. ${ }^{12}$ Eventually, I may reach the paradoxical point of identifying whether or not this novel is, or stages, an unidentifiable object.

\section{Cooking Animals}

Cooking invokes the animal (la bête). Not only but also because flesh is the consummate sacrifice on the altar of the (kitchen) gods, the food stuff par excellence - it's not a meal without meat. La Cheffe's first employers say exactly that. Her memory of working for the Clapeaus is dominated by the cult of meat:

There was the streaky salted pork and pork sausage to cook with very fine leaves of white cabbage, the breaded, grilled fillet steak with melted anchovy butter, there was every kind of kidney [de toutes les bêtes], always sautéed in butter and covered with madeira sauce, rabbit with shallots and mushrooms, tongue gratin, pigeons with peas, veal escalope with pepper sauce, black pudding with onions, or meat served with slivers of poached apple, fried chicken croquettes, Villeroy lamb chops which $\mathrm{Mr}$ Clapeau adored, he would call them his little darlings, he loved them with a thick breadcrumb coating, brown on the outside barely cooked in the middle, he wanted to have the hint of the taste of blood. ${ }^{13}$

In spite, or perhaps because of, Mr Clapeau's phallocentric adoration of the sacrificial substance of the feast, doubt lingers about the nature of such food stuffs, fat and flesh, the hint of the taste of the blood, and their preparation, almost raw or cooked. Derrida reminds us in 'Eating Well' of the political and metaphysical cult of the classic carnivorous subject from which, he argues, there is no absolute escape, no simple 'after' the cannibal-subject. Incomplete animals on the table here indeed - animals literally dismembered, and dead (no spirit, no breath) in the labour of creation: what kind of lethal and complicated works (chef d'oeuvres) are these? Savoir or savoir-faire, these are the children ('little darlings') of love and-or hate as well as skill. La Cheffe will trace a path away from these early experiments, dreaming of an escape-route in immaterial sensuality, even though the unidentifiable object is perhaps precisely a dream, or fancy touched with madness.

Let me ask another question (she asks rhetorically)? Should you kill, or at least watch the slaughter, of the animals you eat? One critique of our disorderly eating today points to so many millions of beasts, especially chickens, factory-born and raised only to exist in misery before an early death (the perverse twin of the decline in number of species - the rise of Franken-chicken). Factory farms: what might once have been a contradiction in terms now easily rolls off the tongue, familiar by repetition. This critique claims further that not only the factory but also the abattoir is too well-hidden from view and from the other senses: the smell of the blood and faeces produced by violent killing is too well disguised, the sound of animal cries of shock and pain is muffled just as much as the vision of the beast bludgeoned, scalded or sliced up is lost or blurred. We do not touch those bodies and they do not touch us, we are not touched. ${ }^{14}$ Rather we receive the sacrifice processed in packages or nuggets - like the communion host, a dry wafer in which only the very vivid imagination can taste bleeding flesh. NDiaye delicately stages this with her unusual la Cheffe (word and persona), the challenge to orthography hidden in the voice, the imagined audible voice of the subjective monologue, or maybe half a dialogue, of the text (the singular article hints but does not 
reveal), an objective affront to the eyes on the page we read, and always marked by a capital letter, another 'head(ing)' for a remarkable woman known only by that name. ${ }^{15}$ La Cheffe is unwilling to be identified by her body, summed up by a dumb little woman's body, even while she lets it serve as a veil of bêtise, so that the non-dupes (as they see themselves) can err. At the outset La Cheffe is always already respectful of the animal body, and more than a body, the material with which she works. She wants to see and touch her meat, pinching the skin of her first majestic chicken from a local farm she visits in person, testing its bones, inspecting its liver. ${ }^{16}$ For her: 'the sole and unique justification for killing an animal lay in the deference, the courtesy and the decency with which you were going to set about working on its flesh, and then introduce it in to yourself mouthful by mouthful'. ${ }^{17}$ But will this courtesy be sufficient to dampen the rising madness (la folie) of the quest for ethical and creative perfection in the practice of lethal production for slow consumption 'mouthful by mouthful'?

\section{The Genre and the Author}

Health warning: If La Cheffe is identified as a roman - it is something that is not true, we cautious and attentive (and very slow) readers might note. It is untrue by definition as the novel is the literary object par excellence de nos jours. In addition, it is a tale told by an acolyte, an apprentice sous-chef, an ephebe in the world of making a living through the death of other creatures, a younger man who is or was a would-be lover. Thus, even within the confines of fiction, it might not be true because he is lying to his interlocutor and/or to himself, and/or he has access only to inaccurate or at least partial (in both senses) information. ${ }^{18}$ And so perhaps there are many layers of conscious and unconscious deceit in this account of a chef - no, 'la Cheffe' - and her exploration of cooking, killing and letting live. NDiaye's signature is the polysemy of fantasy in the real; in the words of Shirley Jordan, she 'conspicuously veers between and tests conceptual extremes so that every incident [...] remains snagged between embodied practice and conceptual exercise [...] compounded by her use of the fantastic'. ${ }^{19}$ This text is more sharply 'realistic' than most, precisely where NDiaye explores the mystery of the creative process. Even so, there is a creation myth whereby the creator is born fully-armed as Athena in the mastery of her tools yet still humbly submits to an infinite apprenticeship. Moreover, she returns to the Garden of Eden, as an end rather than a beginning, for a picture of sublime creation that cannot be identified as a creation within the terms of the novel; in a reverse gesture to Magritte's 'ceci n'est pas une pipe', la Cheffe says 'this is a meal', the ultimate meal, which is not a meal.

The genre remains unidentifiable even if we momentarily set aside the question of autofiction - there are elements of a detective story and of a love story, a misguided love story, maybe an unrequited love story and maybe a queer romance. I shall pause, again, to underline that the narrator of $L a$ Cheffe inevitably plays the part of the lover-detective - as all bio-graphers (or bio-phoners in this case) surely must. ${ }^{20}$ Loving, writing-speaking of the beloved, detecting or at least uncovering-discovering the beloved - none of these are identical but they are all potentially elements of a roman(ce). The subtitle, usually shedding light, misdirects: it could be argued that the woman named la cuisinière in NDiaye's novel, the cook working for the Clapeaus, occupies only a few pages in a long novel. Her partial memory and his many words are as ambiguous as silence. L'Histoire (qu'on ne connaîtra jamais) [The Story/History (which we will never know)] is not only a metonym for all of Cixous's titles, as Derrida contends, but also for many others including La Cheffe: we may know 'a' story but will we ever know what 'the' story is? ${ }^{21}$ 
But perhaps I should begin. I said I would begin at the beginning and then I began before the beginning. In fact, to delay a moment longer, my lengthy preamble on the title has left aside another element of the book cover - the name 'Marie NDiaye', the authorial homonym for Marie NDiaye. Writing of Cixous as 'the author' of Firstdays of the Year [Jours de l'an], and of her fascination with the phrase 'Je est un autre', since her schooldays, Derrida suggests: 'Ce n'est pas elle, mais ce n'est pas une autre [It is not her, but it is not an other]'. ${ }^{22}$ In editions where there is a photograph of the author, one might speak of a cloak of visibility. Like Jordan, who emphasizes NDiaye's reticence in interviews and her unwillingness to be pinned down or identified, I should like to cite Margaret Atwood on the perils of celebrity for a writer: 'the nobody-writer must throw off the cloak of invisibility and put on the cloak of visibility' as he becomes 'Somebody'. ${ }^{23}$ Atwood adds that Marilyn Monroe is rumoured to have said that if you're nobody you can't become somebody unless you're somebody else. ${ }^{24}$ For me these no- or some-bodies implicitly say a considerable amount about both sex and class as well as the general condition of the writer. While famous cloaks of invisibility permit (often a man) to spy unseen, a cloak of visibility forces you to be seen and thus unseen. Monroe is excessively bleached, while Ndiaye's authorial photographs show a black woman's face and body. She resists identification as a postcolonial woman writer even as she feels identified.

\section{Beginnings}

Begin again. Begin better. NDiaye welcomes complex chronologies. The novel La Cheffe begins with a one-sentence paragraph: 'Oh oui, bien sûr, c'est une question qu'on lui a souvent posée [Oh yes, of course, it's a question she was often asked]'. ${ }^{25}$ This is not the beginning of la Cheffe (the persona) of course - that will come a little later. La Cheffe begins with apparent feminine affirmation 'Oh oui' like Molly Bloom or Cixous (or Thessie) 'yes' ${ }^{26}$ The 'yes' is followed with 'of course' - perhaps intensifying the yes-saying, yes, yes. ${ }^{27}$ But no. The 'yes' is the yes of the unnamed narrator of the novel, the monologuer of her life, perhaps her biographer or the teller of a tale of unrequited love, to an interlocutor identified only as 'vous' (the French polite form hiding even the number of interlocutors), confirming, in answer to a question, that a question is frequently asked, indeed asked over and over again. That question, which is, we readers deduce, the impossible question of the truth, the secret, of being a chef(fe), the demand to reveal the truth of the mystery of cuisine (haute cuisine), of creativity, is in fact met by an evasion if not deceit, the veil is not torn aside. The appearance is given of stupidity - this is how la Cheffe evades 'them', the ones who want to know. In another one-sentence paragraph the faithful narrator comments: 'How I loved to see her take pleasure in passing for a woman of limited capacity!' 28 (His love, her pleasure - but only in cuisine or in disguise or evasion.) She delights in passing for a woman of very limited intellectual capacity ('une femme bornée') - whether this be definitional of women or a genus of woman (the brainless birds, the chicks, fodder for men). ${ }^{29}$ You can never underestimate the force of what we might quickly call misogyny in the reaction to a successful woman. ${ }^{30}$ And la Cheffe cannot bear paeans of praise for her cuisine; resisting the institutional machine, she does not want consumers-critics to show off their appreciation with fine phrases. She understands sensations, emotions, and loves the physical manifestations of pleasure aroused by her art, the sensual memory, even dream, that might linger, but words seem to her indecent - all she wants to hear is: 'C'est très bon'. Another one-sentence paragraph 'If she were to be told: that's really good, she would ask for no more, above all no more [pas plus, surtout pas]'. ${ }^{31}$ So we take the step [pas] from yes to no. The art of ultimate intimacy which she enjoys with the one who eats her food, who takes her creation into their body and mind, would be violently stripped naked by verbal description - by the betise of her 
admirers 'How stupid they are [Ce qu'ils sont bettes]', she says - and so they think that 'the inflexible god, the demanding god of the kitchen had chosen to take fleshly form [avait jeté son dévolu, pour prendre chair], in that little woman who is not very easy and a bit stupid'. ${ }^{32}$ What an extraordinary incarnation, god made flesh not in his only begotten son, but in a dumb woman [sotte]. A little woman. A woman who is not easy [facile] in any sense. Eve's double bind: a sin to be easy and a sin not to be easy. This judgement is made because critics can eat her food but they cannot consume her, cannot chew her up and digest her as an interesting little supplement to the meal or to the description of the chef-d'oeuvre (l'homme et l'oeuvre) - she cleverly takes them in by this appearance of stupidity, this performance of bêtise for the clever bêtes (perhaps paraitre bête, bêtre). ${ }^{33}$

This is the beginning of the book - but what about her unknown even 'impossible' origins, 'l'enfance d'une Cheffe', ${ }^{34}$ a literary allusion deployed maliciously by 'vous', the educated interlocutor, so that the narrator, the author of the kind of love-letter-life, might reveal his lack of education? ${ }^{35}$ For he, like la Cheffe, has no real formal literary education - and this is often (mis)taken as a lack of intelligence. Here the implied insult shows how bêtise is weaponized by class and culture - perhaps by a (restaurant) critic, which of course, is what allows it to be a 'skirt' for la Cheffe, a performance developed from the dumb maidservant (la bonne) she was originally hired to be. ${ }^{36}$ Sartre's Lucien in 'L'Enfance d'un chef' ['The Childhood of a Chef'], by contrast, is destined to inherit his father's factory and thus be a boss; his father has made him to be a boss, and also makes him a boss by showing him, for example, how to put on a special voice when speaking to the workers so that they will love and obey him. He also 'earns' this honorific by refusing to shake the hand of a Jew. La Cheffe, on the other hand, comes from a very poor family - and her working-class background is highly significant. ${ }^{37}$ However, having laboured very slowly, I now want to skip rapidly to two scenes in the life of the Cheffe, not her physical origin but her second birth at the age of sixteen - her birth as la Cheffe when she is given a chance as a cook - and then her final scene. ${ }^{38}$ Although it brings overwhelming delight to the consumers, the first meal is shameful in retrospect for the creator because it is perhaps too clever (and NDiaye's very early works are noted for their 'fireworks', ${ }^{39}$ as Jordan puts it) in the tricks it plays with 'chicken'. The final meal, which could hardly be defined as a meal, is pure pleasure for the artist but horror for her guest. The 'fraternity' of semblables created between cook and guest, writer and reader, is a fragile bond - particularly when the 'giver' is also to some extent an outsider, a 'stranger', a woman. Both the primal scene and the scene that marks the consummation of her career, both blends of artistry and trauma for the participants, revolve around chickens, as the raw material for culinary creativity.

\section{Chickens and Scenes of Artistry: From the Simulacrum to the Imaginary Meal}

But why not one more parenthesis, to ask: why chickens? They are the extreme example of the Fall, if such it be, from sacrifice to holocaust in human-animal relations. ${ }^{40}$ These beautiful feathered friends have such a very long history of cohabitation with human beings across most of the globe, often not as natives but as exotic and precious strangers. Even today in Britain, shameful home to Bernard Mathews and his like, backyard chickens, once the resource of the less well-off, have risen again as the beloved pets of the liberal bourgeoisie. Chickens were not first domesticated as a source of protein (flesh and eggs), or certainly not merely for food. ${ }^{41}$ Archaeologists have found complete chicken remains alongside human remains in ancient graves, suggesting prized goods if not companions. They played a key role in religious ritual and their feathers were valued. Of course they are also bred to fight - both a particularly spectacular cruelty (unlike the hidden violence of the industrial cage) and, like bullfighting, a practice which involves cherishing and veneration - and cockfighting continues even in Europe today. Chickens had a particular nourishing role in the French 
imaginary of food; Henri IV is believed to have declared around 1600 that he would ensure that no one in his kingdom was so poor that he could not afford 'a chicken in his pot'. As protein they have shifted from the apex of the weekly communion around a table to be the animal par excellence of the Anthropocene. Now industrially across the globe - we have 'chicken':

Closely linked to that world of crime [the disavowal of vicious cruelty to chickens], is the outrage of naming. People say chicken in the singular when they are actually talking about chickens in the plural. Mixing their metaphors in a vague toilet panic, they try to flush out - meaning flush away - their knowledge of what they are doing by resorting to an abstract plural, a strictly fictional turn of phrase, as part of an elaborate strategy to gloss over the reality of what they are doing. In this seemingly small but telling detail they behave precisely in the manner of headless chickens. ${ }^{42}$ Royle suggests, with his 'Hides' in An English Guide to Birdwatching, that 'ornithomorphic' linguistic play tends to be simultaneously revealing and concealing: 'Of all the idioms whereby English speakers abuse the avian world, none is more perhaps more nauseating and abject than killing two birds with one stone ${ }^{43}$ Chickens come home to roost, and of course chickens have a very special place in philosophical discourse as the model of the problem of causal antecedence: which came first?

La Cheffe's origin or second birth is achieved through sacrifice, consummated with the selection of a splendid victim, the ceremonial preparation of the corpse, and, finally, the incorporation of the transformed, transfigured flesh. Carnophallogocentrism is celebrated here to the nth degree. La Cheffe's offering is a costly work of artifice (costing money, time and a life), a miracle received with anxious, uneasy rapture by her audience, her bosses who then become enthralled, her servants, her prisoners. ${ }^{44}$ The unctuous flesh is cut from the sumptuous chicken's body, minced and mixed with other substances, including five eggs, then replaced on the carcass in a simulacrum of the chicken's shape. Finally, using the beautiful corn-coloured skin, she dresses the chicken once again to complete the illusion, and then surrounds the huge bird with small vegetables. ${ }^{45}$ Despite the apparent extraordinary mastery of her art already in her first adolescent experience of cooking, ${ }^{46}$ la Cheffe, in a lifetime of discipline and dedication to her art, will always look back on this juvenilia with shame - it is a botched scribble, ugly in her eyes because it did not respect the integrity of the material - it was indeed a brutal violation of the flesh. 'How la Cheffe would hate simulacra [le simulacre], later on' ${ }^{47}$ She is always grateful to the living elements that make up her creations and wants to honour them appropriately. ${ }^{48}$ So her first ever meal begins and ends well with fish soup and fruit tart, ${ }^{49}$ but its crowning glory was 'a savage joke'. ${ }^{50}$ High (culinary) art, in its breaking down of the animal body and reassembling it in a golden robe, quotes, as if knowingly, the chicken nugget.

I note that La Cheffe always seeks visual as well as olfactory, gustatory and haptic satisfaction in her presentation of her dishes as a feast for the eyes, in her attention to colours and shapes on the dish - though coming to resist the spectacle of (dis)simulation. Those who have eaten her food might remember simply 'three distinct and bold colours on the opaline white dish'. ${ }^{51}$ For her first meal:

[I]t mattered to her that they saw the whole of the ochre soup between the black walls of the pot. [...] Later it was important to her not to present things where the form was to be admired, nothing which could push you into ecstasies, but, on the contrary, arrangements of dishes or plates of a beauty so delicate, so sober, so rigorous that it only struck you if your gaze was open and ready to be overwhelmed [ravished], if you desired it. ${ }^{52}$ 
The ideal recipient is not the stupidly clever detective-critic, but, in a way, the one who is hospitable to being overcome, becoming bête. She does not serve the Clapeaus herself because she wants them to lean over the humble cooking dish she produces in the place of their usual decorated tureen: 'forced to take notice of the basic and pleasing equilibrium of substances and colours [...], la Cheffe hopes that the sovereign assurance of the pot would make the Clapeaus forget the tureen painted with little roses, would make them forget that tureens with little roses existed' ${ }^{53}$ The unnecessary decoration is also a simulacrum of nature. The unconscious response of the spectators/eaters to her dishes, without even her knowledge or deliberate design, should awaken them to other harmonies 'a supplement of perception and of sensibility'. ${ }^{4}$

Her final meal, three days before her death, is rather different. Throughout her culinary career, she would see 'beautiful and abstract images of accomplished structures [...]. And when I used to ask her what the things she saw looked like, she would sketch sibylline forms in the air, explaining vaguely that she was searching for ideal compositions' ${ }^{55}$ Towards the end of her life she begins, the narrator deduces, to hate what she had always loved: 'imperceptively, she would remove ingredient after ingredient from her dishes, keeping herself within the limits of an exquisite austerity but on the border, I said to myself anxiously, of falling into nonsense [le non-sens]' ${ }^{56}$ She invites the narrator to Sunday lunch with friends in an auberge near her childhood commune of Sainte Bazeille, closing her restaurant for once. He finds her waiting there alone in 'un jardin enchanté'. ${ }^{57}$ The most obvious reference here is to the Garden of Eden where a man and a woman would live with the animals, without death, without mastery and slavery, but, as her table is on the grass, the words also evoke Manet's déjeuner sur l'herbe, the picnic with naked women (perhaps the artist's model as meat if only for the eye) and clothed men. She is alone, but:

in the midst of black chickens and white chickens who were freely pecking about around cherry trees laden with fruit. Between the trees carrots, rocket, peas and beans grew haphazardly which the plump, clean chickens were nibbling here and there, with a strange delicacy, and as if, in fact full up [already satisfied?], they were only doing it for the form, to meet what the picture demanded. ${ }^{58}$

I should briefly point to the 'exigences du tableau' vivant (not a nature morte, what we English bizarrely call 'still life', with a different macabre beauty) in the quotation above. Even the birds do not really want to eat, companionably mirroring la Cheffe's exorbitant asceticism.

When the narrator, sipping fine wine in the sun, on the final page of the 'roman', gently says that he is hungry, instead of summoning a pot au feu or other expected nourishment, la Cheffe points to the chickens, young vegetables and ripe cherries:

She told me that the meal was there, sober, magnificent and perfect.

We could imagine ourselves the taste of each element as of the elements combined. She could never invent anything simpler nor more beautiful, and so our wine, that excellent Graves, would suffice for our lunch which constituted the crowning glory, she said, painfully serious, of the long ceremony that had been her career. ${ }^{59}$

The Garden of Eden, where no animals are killed, is thus the end point rather than an origin; it is where the characters arrive. La Cheffe's career of curiosity and knowledge about food begins with eating what is shameful, not an apple but the savage joke of the re-created chicken; it ends in innocence. Here cuisine is a telepathic performance, the transformation from raw to cooked taking place in the mind alone, or, perhaps, in all the senses bar those located uniquely in mouth, throat and belly, between two friends, a man and a woman. 
This pure and blissful chef-d'oeuvre is also trauma for the interlocutor who is her only guest, her only friend for life - here memorializing her after death has parted them, keeping her inside him but no longer a secret, rather endless material for production of words, vomiting her out, stripping her bare, in the long monologue of the book. The meal without pain is acutely painful for the lover, who detects madness. Linking the relationship between two friends, a man and a woman, to the communion between Cixous and Derrida, it is worth recalling that Derrida seeks to be convinced by Cixous about life over death, preparing to receive grace rather than the 'coup de grâce', yet his conviction remains that he is condemned to die, and that this is (one of) the truth(s). The argument is without end. ${ }^{60}$ For La Cheffe, perfection as starvation, a déjeuner containing its opposite jeuner (to fast), ${ }^{61}$ delighting the mind and the senses (sight, smell, sound) while refusing to incorporate other living bodies (not only animals but le vivant in general), and thus end the simple perfection of their lives, will lead to death - is this ethical and aesthetic perfection ultimately non-sens since a life must end $?^{62}$

\section{The Logical Conclusion}

The logical conclusion of life is death, and taking things to the logical conclusion is non-sens. In this quasi-self-portrait, the self as author is rigorously othered as 'La Cheffe', perhaps, like Cixous, fascinated by Rimbaud's 'je est un autre'. She chooses death with a quest for artistic and sensory perfection figured as a refusal to take life - and so perhaps she is, after all, saying 'yes' to life (other lives, others' lives). Any consumption touches cannibalism, that extreme eating at the limits of the edible, as Derrida thinks at, and on, the limits of thought - or language - and even vegetarians cannot escape sacrifice, cannibalism, as he suggests in 'Eating Well' to the horror of animal rights philosophers. ${ }^{63}$ Why would La Cheffe more particularly have been a cannibal? Only in so far as animals, unusually, are considered as semblables. La Cheffe is so often compared to an animal (for instance, a bull ${ }^{64}$, a donkey ${ }^{65}$, a $\operatorname{dog}^{66}$ ) or to a collection of animals ${ }^{67}$ - and the reader is left to decide whether these are 'simply' the narrator's metaphorical way of drawing on particular animal traits, or whether it makes a more general point about la Cheffe - or about animals. For la Cheffe, sovereign, ${ }^{68}$ whose literacy is marginal and memory phenomenal, a list is a pense-bête ${ }^{69}$, and bêtise a refuge. Having hesitated over consuming, over taking up space, over being visible for most of her life, in the end La Cheffe chooses a radical culinary semi-art of almost nothing (after all she has a glass of wine so not quite nothing), but then her lover-friend (ami) constructs a 'life' for her even if it is a roman. ${ }^{70}$

So is this novel a ULO? Does unidentifiable mean that we keep identifying something (and failing) or that we suspend identification? The designation must lie somewhere between (entre) those objects, insofar as they are as impossible as living off thin air or living as a cannibal, insofar as they are made of pure brilliance and bestial betise, and the eye of the beholder who has learned to suspend judgement or at least say no more than ' $C$ 'est très bon', a consummate banality that could equally be the heartfelt simplicity desired by the creator. The impossible question: how was it for you? The only possible answer: it was great. This is why, from time to time, we fall into undecidability or feint - the decidable question is already decided and thus no question at all. Is there more readerly-writerly pleasure or challenge in identifying or in complicating identification? The works of NDiaye are usually located by the sex and race of their author - critics chase the postcolonial and feminist significations and political meanings, of every line of NDiaye's works. Sometimes she asks for it - sometimes she does not. Yes and no. Derrida is not known for writing on women authors - except, and it is a rather important exception, H.C., the greatest living writer in French today, ${ }^{71}$ an unusual 
decision for J.D., a judgement or identification made with amitié - as chicken and egg. Thus perhaps he would be quite unworried by the notion of reading NDiaye, just for a moment, aesthetically and philosophically as much as politically, for her mise en abyme of the question of writing-reading, of cultural consumption alongside physical consumption, the spirit alongside the letter, at the edge of meaning.

\section{Bibliography}

Atwood, Margaret. Negotiating with the Dead: A Writer on Writing (Cambridge: Cambridge University Press, 2002).

Derrida, Jacques. The Animal That Therefore I Am. Translated by David Wills. New York: Fordham University Press, 2008.

Derrida, Jacques. The Beast and the Sovereign, vol. 1. Translated by Geoffrey Bennington. Chicago and London: University of Chicago Press, 2009.

Derrida, Jacques. "'Eating Well”, or the Calculation of the Subject'. Translated by Peter Connor and Avital Ronell, 255-87. In Points . . Interviews 1974- 1994, ed. Elisabeth Weber (Stanford: Stanford University Press, 1995).

Derrida, Jacques. 'Foreword'. Translated by Eric Prenowitz, ix-x. Hélène Cixous, Stigmata: Escaping Texts. London and New York: Routledge, 2005.

Derrida, Jacques. H.C. pour la vie, c'est à dire... Paris: Galilée, 2002.

Ellmann, Maud. The Hunger Artists: Starving, Writing and Imprisonment. London: Virago, 1993.

Hanrahan, Mairéad. Cixous's Semi-Fictions: Thinking At the Borders of Fiction. Edinburgh: Edinburgh University Press, 2014.

Jordan, Shirley. (2016). Looking for Marie NDiaye: Autofictional Fragments from Autoportrait en vert to Cheffe, roman d'une cuisinière. [ONLINE]. 9 March 2017. Available from: https://www.sas.ac.uk/videos-and-podcasts/culture-language-andliterature/looking-marie-ndiaye-autofictional-fragments. [Accessed: 1 January 2019].

Jordan, Shirley. Marie NDiaye: Inhospitable Fictions. Cambridge: Legenda, 2017.

Kamuf, Peggy. 'Tele-types (Yes, Yes)'. In A Derrida Reader: Between the Blinds. Edited by Peggy Kamuf. New York: Columbia University Press, 1991, 459-62.

Ndiaye, Marie. La Cheffe, roman d'une cuisinière. Paris: Gallimard, 2016.

Richardson, Samuel. Clarissa, or the History of a Young Lady. Edited by Angus Ross. Harmondsworth: Penguin, 1985.

Royle, Nicholas. An English Guide to Birdwatching. Brighton: Myriad Editions, 2017. Still, Judith. Derrida and Hospitality. Edinburgh: Edinburgh University Press, 2010.

Still, Judith. Derrida and Other Animals: The Boundaries of the Human. Edinburgh: Edinburgh University Press, 2015.

Still, Judith. 'Disorderly Eating in Marie NDiaye's "La Gourmandise" OR The Solitary Pleasure of a Mère de famille'. In Disorderly Eating in Contemporary Women's Writing. Edited by Shirley Jordan and Judith Still. Journal of Romance Studies. Forthcoming.

Still, Judith. 'Thoughts From France on the Animal-Human Borderline: Derrida and Animal Rights Philosophers'. In French Though and Literary Theory. Edited by Irving Goh. Abingdon: Routledge, forthcoming.

Sykes, Naomi. Beastly Questions: Animal Answers to Archaeological Issues. London: Bloomsbury, 2014.

\section{Notes}


${ }^{1}$ See Hanrahan, Cixous's Semi-Fictions.
${ }^{2}$ We might note in passing the subtle difference between acronyms pronounced as words such as
OVNI, and initialisms such as UFO pronounced as sequences of letters.

${ }^{3}$ See Derrida, H.C. pour la vie, e.g. 9-10. The recurrently sexual difference also echoes through 'her' dead fathers and living mother.

${ }^{4}$ The play in French dances through homonyms, quasi-homonyms, homophones or quasi-

homophones: à coté de, du côté de, de son côté, quote... It is never simply idle play - drawing the reader into philosophical speculation about the meanings of sides and siding even as it highlights the poetic polysemy of this difficult writing.

${ }^{5}$ Derrida, H.C. pour la vie, 40.

${ }^{6}$ To take one example, the journal Expressions maghrébines did devote a special issue to Cixous in only its second volume, 2:2 (2003), but she has rarely featured in their pages since then, and Derrida, a fellow Maghrebian, is also rarely the subject of an article in this journal devoted to writers hailing from North Africa. The imaginary of the identification as 'Francophone' is a complex one, and NDiaye plays with attitudes to race, ethnicity and location in many of her works - refusing, to the frustration of many of her readers, to situate characters in a simple way, and often racially queering the (racist or at least racisizing) tracking of accent, hair texture, facial features or shade of skin in order to place characters who wish to present themselves otherwise or not at all. Cixous is more often labelled, or placed in a list, as a 'French feminist'; see Derrida's remarks on this identification in H.C. pour la vie, e.g. 121-2.

${ }^{7}$ I was first alerted to the notion that La Cheffe is in some respects a portrait of the artist herself by Shirley Jordan. See her 2017 podcast 'Looking for Marie NDiaye'. She notes the title of NDiaye's critically-acclaimed autofiction, Autoportrait en vert [Self-portrait in Green], and the description of La Cheffe's signature dish (although not her favourite dish), at the height of her fame, as 'le gigot en habit vert', a lamb dressed in green (coated in herbs).

${ }^{8}$ See Derrida, H.C. pour la vie, 13 , for translation, and the untranslatable, as quasi-parricide.

${ }^{9}$ Un point c'est tout. Deux-points implies there is more to say.

${ }^{10}$ In fact in this instance the masculine form le cuisinier can mean a cookery book - arguably a more elevated object than a stove. In its more common meaning as cook it is both 'a person whose job it is to cook' (a role e.g. as a servant) and ' a person who knows how to cook' (and an ability or knowledge of cooking 'elle est très bonne cuisinière' is the example), Petit Robert.

${ }^{11}$ The real cuisinière in the novel is the Clapeaus' cook - emblematic of the kind of rich cooking and perverse master-servant relationship which fills la Cheffe with horror. The cook had power over the food-adoring couple as she officiates in their cult, and so believes she is safe in refusing to go to their holiday home in the Landes region. Scared at the thought she will not return, they turn to their young 'bonne' [maid] to act as a short-term substitute. In the event, she immediately eclipses her predecessor - the classic supplementary move.

${ }^{12}$ See, for example, Derrida's repeatedly suspended analysis of La Fontaine's 'The Wolf and the Lamb' in The Beast and the Sovereign, vol. 1.

${ }^{13}$ NDiaye, La Cheffe, 50.

${ }^{14}$ She is worried that the Clapeaus may not have wanted to touch her peach tart - a literalization of the expression - it is too good to eat (99).

${ }^{15} \mathrm{La}$ Cheffe, the narrator (je), la Cheffe's daughter (la fille), the interlocutor (vous), the most important characters are never given proper names - simply one syllable descriptors - unlike the Clapeaus, Declaerte, Millard (all people for whom la Cheffe works). The only character to be given both a first and last name is the narrator's wife and employer, the wise Sophie Pujol who plays a very minor part. The narrator's daughter (la Cheffe's granddaughter) is called Cora $(194,226)$ - perhaps a telling name with its echo of Khora, maiden, Persephone, space, receptacle. I mention this only for the resonance with H.C. and Derrida's analysis.

${ }^{16}$ NDiaye, La Cheffe, 70.

${ }^{17}$ Ibid.

${ }^{18}$ In the 2017 paper cited below, Jordan argues that the form of the text is an interview.

${ }^{19}$ See Jordan, Marie NDiaye: Inhospitable Fictions, 6; and e.g. 9-13 for 'the saturation of her world in the fantastic' (9); Jordan also gives references to most key work on Ndiaye. 
${ }^{20}$ He seeks knowledge of la Cheffe out of love (91) - her daughter has a different story to tell out of loathing. When the narrator secretly, guiltily, visits the key locations of la Cheffe's early life he refers to his 'little schemes as a detective' (130).

${ }^{21}$ Derrida, H.C. pour la vie, 17.

${ }^{22}$ Ibid., 38.

${ }^{23}$ See Atwood, Negotiating with the Dead, 134.

${ }^{24}$ Ibid.

${ }^{25}$ NDiaye, La Cheffe, 9.

${ }^{26}$ See Derrida, H.C. pour la vie, e.g. 83-5, 103. See Derrida and Hospitality (232-4) - this chapter also contains an analysis of Derrida's 'Eating Well', a key intertext for this essay.

${ }^{27}$ See Kamuf, 'Tele-types (Yes, Yes)', 462.

${ }^{28}$ NDiaye, La Cheffe, 10.

${ }^{29}$ I cannot resist citing James Harlowe: 'Daughters are chickens brought up for the tables of other men'. See Richardson, Clarissa, 77.

${ }^{30}$ See Derrida, H.C. pour la vie, 118.

${ }^{31}$ Almost all the paragraphs in this long book are one sentence - whether short or very long. But analysis of this would be another essay. NDiaye, La Cheffe. 11.

${ }^{32}$ Ibid., 13.

${ }^{33}$ See Still, Derrida and Other Animals, e.g. 11-13, 129-30, 202-3, 306 for analysis of Derrida's use of bete and bêtise in The Beast and the Sovereign.

${ }^{34}$ NDiaye, La Cheffe 17.

${ }^{35}$ Jean-Paul Sartre's 'L'Enfance d'un chef' is one of four short stories in the collection Le Mur (1939).

${ }^{36}$ Derrida analyses Paul Valéry's Monsieur Teste (1926) over a seminar in his The Beast and the

Sovereign (1,183-205), suggesting that a number of key sentences such as 'la bêtise n'est pas mon fort', an untranslatable sentence suggesting something like 'stupidity is not my strong point [or forte]' could be ascribed to author, narrator or protagonist - there is an uncanny mirroring or echoing between the three, all of whom define themselves against animal stupidity. The name Teste can of course be related to head (chef) - and testes - masculine rationality writ large.

${ }^{37}$ She grows up in animal innocence and ignorance, then at fourteen and a half (in the mid-1960s) her impoverished parents send her to work for the Clapeaus, a couple in Marmande, who are looking for 'une petite bonne' - she is their servant and also initially at the mercy of the cook and the gardener who treat her as if she did not exist. One of the reasons that la Cheffe is made miserable by the award of a Michelin star is that her customer base changes in favour of the rich and pretentious - it is a kind of betrayal of her origins, at least in the story told.

${ }^{38}$ I should note that the narrator's second birth is his encounter with La Cheffe - his life is his obsessive love for this culinary artist.

${ }^{39}$ Jordan, Looking for Marie NDiaye.

${ }^{40}$ In The Animal That Therefore I Am, Derrida discusses the huge shift in our relation with animals since the end of the eighteenth century, a period which is widely regarded as the location of the third revolution in relations between humans and animals. This agricultural revolution involves scientific breeding, the forerunner of industrialization of food production. Derrida points out that exploitation, training, hunting, experimentation and so on did not begin in the Enlightenment but are as old as man and 'what he calls his world, his knowledge, his history, and his technology' (25). Yet in the last two centuries there has been a 'bouleversement' thanks to the conjoined development of 'savoirs' and 'techniques' - with genetic experimentation and the manipulation of the genome, industrialization of food production (25), and the advent of mass species extinction.

${ }^{41}$ See Sykes, Beastly Questions.

${ }^{42}$ Royle, An English Guide to Birdwatching, 270. Royle cites some of the notorious practices of today's 'chicken production' such as 'beak trimming' to avoid cannibalism - a violent mutilation causing lasting pain - typically described as if a mere haircut (271-3).

${ }^{43}$ Ibid., 265.

${ }^{44}$ NDiaye, La Cheffe, 120, ff.

${ }^{45}$ Ibid., $73-4$.

${ }^{46}$ We might note NDiaye's great youth when she first started publishing and winning accolades. 
${ }^{47}$ NDiaye, La Cheffe, 74.

${ }^{48}$ Ibid., 71.

${ }^{49}$ This tart will become a signature dish, but its role in this first supper, with its excessive tartness, is to liberate la Cheffe's masters temporarily from the enthrallment, even enslavement, brought about by the overwhelming spectacular chicken. La Cheffe's reluctance to indulge diners' child-like fondness for sweets or for cream, 'her almost fanatical frugality' (93), her lack of interest in desserts as treats, is another story - and one which might intersect with the difficult mother-daughter relationship which threads through the narrative. The cook, on the other hand, indulges the Clapeaus' declared guilty passion for sugar and fats as an alibi for their real taste for meat (96-7).

${ }^{50}$ Ibid., 119.

${ }^{51}$ Ibid., 14.

${ }^{52}$ Ibid., 116.

${ }^{53}$ Ibid., 117.

${ }^{54}$ Ibid.

${ }^{55}$ Ibid., 137.

${ }^{56}$ Ibid., 273.

${ }^{57}$ Ibid., 275.

${ }^{58}$ Ibid.

${ }^{59}$ Ibid., 276. The name of the wine she chooses echoes her seriousness.

${ }^{60}$ Ibid., 136. Cixous's words: 'We are not going to die' are also true. How is this possible?

${ }^{61}$ Self-starvation can of course have many (intersecting) meanings from the pathology of anorexia, through political hunger-strikes to spiritual fasting (see Ellman, The Hunger Artists) the latter perhaps most relevant here although elsewhere NDiaye represents what would more easily be labelled eating disorders. See Still, 'Disorderly Eating'. St Theresa tastes the pleasure in pain and disgust - tasting her lover-god's flesh and blood in mystic cakes; see Hanrahan on Cixous's Souffles in Cixous's SemiFictions, 109.

${ }^{62}$ See Derrida, "'Eating Well"'. Yet the good mother is not necessarily the one who fills the child, but the one who weans the child - making the child hungry with her inky-black milk - in Cixous's riff on Kierkegaard. See Hanrahan, Cixous's Semi-Fictions, $102 \mathrm{ff}$. La Cheffe often seems to treat the narrator as a son although he longs to be a lover. He recalls that, when he first enters her kitchen and is desperate to impress, she is hard on him and does not explain things - but on reflection this tough love means he finds his own way to excellence (214-16) - the child has to be weaned.

${ }^{63}$ See Still, 'Thoughts From France on the Animal-Human Borderline: Derrida and Animal Rights Philosophers'.

${ }^{64}$ NDiaye, La Cheffe, 134.

${ }^{65}$ Ibid., 164.

${ }^{66}$ Ibid., 204.

${ }^{67}$ Ibid., 76, 77.

${ }^{68}$ Ibid., 90.

${ }^{69}$ Ibid., 65.

${ }^{70}$ In terms of life after life: La Cheffe has a daughter who has a daughter (the child of the narrator) who decides to start a restaurant named chez Gabrielle - the angel - elle. Maybe this elle is la Cheffe reborn.

${ }^{71}$ Derrida, 'Foreword', x. 